\title{
Conjectural History in Kazuo Ishiguro's Novels: A Pale View of Hills, When We Were Orphans, and The Buried Giant
}

\author{
El Habib EL HADARI \\ $\mathrm{PhD}$ student in Interactions in Literature, Culture and Society, Sultan Moulay Slimane University, \\ Beni Mellal and ELT supervisor at the Directorate of Beni Mellal, Morocco
}

\begin{abstract}
Upon leafing through the pages of Kazuo Ishiguro's works, it is easily discerned that there is a laudable attempt on the part of him to make of history an integral part of the fabrics of his novels. There is a remarkable endeavor to plow up past events and paint them with a tinge of fiction. There is that constant oscillation between the past and present. The narrative structure of his novels is fundamentally carried through the memories of their characters including the protagonists- the first-person narrators. Taking this into account, there is a ringing plea to question the rationale behind Kazuo's heavy reliance on memory and deliberate use of history. This article seeks to shed light basically on the conjectural dimension of history use in Ishiguro's literary works, focusing namely on A Pale View of Hills, When We Were Orphans, and The Buried Giant.
\end{abstract}

Keywords: Conjectural history, facts, opinions, interpretations, forgetfulness, and journey

DOI: $10.7176 / J L L L / 56-02$

Publication date:May $31^{\text {st }} 2019$

\section{Introduction}

Being concerned with history is deliberate for Kazuo Ishiguro. According to him, the act of remembering or forgetting the past is a societal issue. It does not concern only individuals but societies at large. On March the 17th, 2015, in an interview conducted by Tina Srebotnjak in the Appel Salon, he expresses his interest "in this question: how does a nation, how does a society decide when it is better to remember things? And when it is better to keep certain dark memories just buried?" He states that many "societies grapple with this question: to what extent should we remember our past? To what extent should we forget it?" Really important to note is that Ishiguro's use of history is basically conjectural in nature.

This concept of conjectural history was first used by Dugald Stewart in the 1790's in his biographical account of his friend Adam Smith. It simply refers to the process of superseding historical facts with conjectures to fill in certain gaps in human history. In this context, Stewart (293) says that there are moments when there is a necessity to replace or supplement facts with conjectures. This means that people interested in history look basically for facts and evidence, but in cases of the absence of this factual evidence, they resort to conjecture to compensate for it. This conjectural gap-filling dyes history with a special fictional touch.

Resorting to conjecture in dealing with history is a debatable issue. Some say that being conjectural is a way to neglect facts and evidence and favor theory [Meek (1976 231) and Coleman $(1980,775)$ when they comment about Adam Smith's dealing with historical facts]; Wightman (1975 54) accepts this gap-filling when there is no direct evidence (cited in ibid). Brewer (2008, 5), calls this conjecture a judgement that the historian has always to use "to construct a comprehensible narrative". This is to say that the historian's personal touch is always present when it comes to narrating stories using both facts and conjectures.

Conjectures are no longer attractive to the cult of facts. Such thinkers as Ranke in the 1830's describe the task of the historian as showing things as they really happen, giving a sort of faithful microscopic meticulous account of facts as they are without any fictional cosmetic additions. The Positivists, a group of Western philosophers who advocate the idea that data should be collected basically from experience, say that facts should be ascertained first and then conclusions can be drawn from them (cited in Carr Hallett, 2008: 9). Here, facts are distinguished from conclusions. Carr Hallet (2008: 9) calls this the commonsense view of history which is seen as a corpus of ascertained facts. He compares facts in documents to fish on the fishmonger's slab and the task of the historian is to collect them, take them home, cook and serve them in whatever style he or she wants.

The idea is that "first get your facts straight, then plunge at your peril into the shifting sands of interpretation - that is the ultimate wisdom of the empirical, commonsense school of history" (ibid, p 10). Facts are the starting-point in history, and interpretations are the spices which give a special flavor to it. Thus, facts are given the top priority. This is reminiscent of C. P. Scott's dictum: "Facts are sacred, opinion is free" (ibid). It is also reminiscent of A. E. Housman's quote: "Accuracy is a duty and not a virtue" (ibid). Giving accurate facts is the historian's responsibility that he or she should not be praised for. Carr Hallet (2008, 10 and 11) compares "praising a historian for his accuracy" to "praising an architect using well-seasoned timber or properly mixed concrete in his building".

Upon reading his works, it doesn't require much to spot Kazuo's straightforwardness in the use of history and the role it plays in chronicling the changes that occur to human values as time passes on. His characters 
militate against the possible negative imprints that history can have upon their values and morals as individuals and communities. He once said: "What I started to do was to use history .... I would look for moments in history that would best serve my purposes, or what I wanted to write about" (Quoted in Webley, Alyn, March 2006). This means that the recurrence of history in his novels is not a coincidence. It is intentionally included and utilized. There is certainly a driving force behind it.

In so many instances in the novels of Ishiguro, the use of history is conjectural in the sense that he has resource to imagination and fiction to fill in the gaps which do not allow a better understanding of several historical events. He makes use of "conjectures" or "likely stories" to account for the missing evidence in history and dispatch the historical news in a different way. This is to say that in narrating the stories, his personal touch as a novelist is clearly visible. It is history spotted through the lenses of fiction. To have a clear idea of this inclusion of conjectures in the fabrics of Ishiguro's works, it sounds very helpful to consider some examples from A Pale View of Hills, When We Were Orphans, and The Buried Giant. The focus will be laid on three main points: the manifestations of Ishiguro's use of conjectural history, the rationale behind its use and its implications for modern societies.

\section{Manifestations of Ishiguro's Use of Conjectural History}

There are different aspects which show Kazuo Ishiguro's conjectural use of history. In his A Pale View of Hills, there are so many historical contexts which display his concern with what happened in Japan, his country of birth, using his special fictional touch. . He refers, for instance, to Nagasaki Peace Park when Ogata-San asks his daughter-in-law, Etsuko, to go around the city of Nagasaki like tourists do. The place is real and has its own historical dimensions not only in the Japanese collective memory but in the international one as well; but the characters and linguistic interactions surrounding it are the products of the writer's fiction and imagination. He depicts his imagined Japan in the wake of the Second World War. He selects special real historical moments and pours an inflow of imagination on it.

The fall of the Atomic bomb on Hiroshima and Nagasaki in 1945 by the American military forces with the assent of the United Kingdom, and Japan's recovery from it both physically and emotionally constitute one of the main themes in Kazuo's A Pale View of Hills. The suffering of the Japanese at that time has been fictionally chronicled in this novel. The tragic event and the damage it brought about are recorded through the imaginative use of the written word. The historical fact is the same but the way it is presented and dealt with by Ishiguro differs from that of the historians. Through likely stories (conjectures), the Park is brought to the front. It is conjecturally placed in the spotlight.

Ishiguro also makes reference to the period following the Second World War in 1945 when General Douglas MacArthur, the Supreme Commander of the Allied Powers, was chosen to lead the allied occupation of Japan which lasted from 1945 to 1952 "with the approval of the heads of state of Great Britain, China and Russia" (Koch, Kris, 1999: 5). This occupation marked the surrender of the Japanese armed forces. Ishiguro mentions this occupation and describes the damage Japan witnessed after the war as he imagines it given the fact that he had never visited Japan before he wrote the novel. He imaginatively takes his readers back to the historical period when Japan was occupied. It is the period which signaled the breach of an old military tradition in Japan: no for surrender. The Japanese armed forces were obliged to surrender under the terrible bloody tragic impact of the fallen bomb for the first time in her history.

The conjectural use of history is heavily present in his fifth novel, When We Were Orphans, in which Ishiguro, with a great fictional dexterity, makes references to some historical events, dates, places and figures in a conjectural way. It generally looks like a detective novel in which the use of history is fictionalized. One of the examples to cite in this context is the mention of the International Settlement in Shanghai. Historically speaking, "at the conclusion of the First Opium War (1840-42), Shanghai was opened to Western trade as stipulated in the Treaty of Nanjing on November 17, 1843 [...] Shanghai was one of a handful of Chinese ports selected by Western countries to be opened in the 1840s" (Keller, Wolfgang, et al., 2012, P. 5). The characters, conversations, events, and feelings which surround the Shanghai Settlement in the novel are the creation of Ishiguro's imagination. It is Ishiguro's imagined settlement.

Another manifestation of the conjectural dimension of Ishiguro's use of history in When We Were Orphans is the intermittent mention of the opium trade and its impacts on the whole Chinese nation. The trade is historically recorded, but the way it is dealt with and discussed in the novel emits an aroma full of imagination. Christopher Banks' mother is not a real character. It is Ishiguro's product. She is given a strong voice which represents strength, beauty and values of respect and dignity. She gets engaged in a moral altercation with Mr. Wright, the inspector who works for the company of "Morganbrook and Byatt [which] imports opium from India on the sly and, with the help of local warlords" (Anastas, Benjamin, 2000). She reveals her strong personality when she openly criticizes the trade and the policy of the company. This fictional feminine voice represents all those who animadvert upon the opium trade in China.

Bringing homage to Sir Edgar Algernon Robert Cecil during the Meredith Foundation dinner especially 
"for his role in building the League of Nations" (When We Were Orphans, 26) in the wake of the First World War is another example of the conjectural use of history in Ishiguro's literary fiction. Sir Cecil is remembered basically "for his involvement in and promotion of the League of Nations and international peace after the First World War" (Johnson, G, 2010: 185). The linguistic interactions of Sir Cecil with and his marriage to fictional characters of Ishiguro's creation show the skillfulness of Ishiguro in coloring historical facts with fiction through conjectural stories.

The way history is used in Ishiguro's last novel The Buried Giant (2015) is no longer an exception. It is actually a depiction of one of the emotive journeys of memory towards what he calls a blank historical period of England's history (the fifth and sixth centuries). Teo, Yugin (2014) thinks that "Kazuo Ishiguro's novels frequently depict (...) emotive journeys of memory". The Buried Giant is a journey in time, space, fiction and fantasy the purpose of which is to rediscover what happened exactly before England became England. It is the period associated with the Anglo-Saxon invasion of Britain.

In his response to a question about what inspires him to set The Buried Giant in Britain in around the fifth or sixth century in an interview on TVO, conducted by Piya Chattopadhyay on July 22 2015, Kazuo Ishiguro considers this historical period as interesting, describing it as "a kind of blank which is very appealing to a novelist". The novel has come to fill in that blank. No historians, according to him, can tell us what exactly happened in that period. The blank period he talks about stretches from the year 410 when the Romans left Britain to around 480 or 490 when the Anglo-Saxons settled in Britain. For him, it is a mysterious period full of historical events and secrets that need to be shoveled, unearthed and highlighted.

According to Ishiguro, there was some sort of ethnic cleansing or genocide committed against the indigenous Britons who were wiped out, and then, all of a sudden, everything turned out to be Anglo-Saxon, including the language itself. He expresses his preoccupation with these questions: how did all this happen? And how did these immigrating groups settle there during that blank period? He believes that these questions have been neglected by historians for one reason or another. He feels the need to think about these questions, and, hence, the necessity to fill in this historical void. In this way, he explains his choice to set the story of his novel "in that time just before England becomes England" (ibid). For him, it is the period when the Britons were able to co-exist with the neighboring tribes and "live in a relative peace for about a generation" and mutually respect each other's cultures until the coming of the Saxons which marked the end of all this (ibid)..

In this novel, there is a reference to a sort of a pre-scientific society which credulously believes in superstitious ideas, myths, and some supernatural beings such as ogres, sprites and pixies which were characteristic of England at that time. There were a lot of phenomena which people could not scientifically explain, and thus they resorted to superstitious beliefs and ideas. One of the examples that Ishiguro cites in this context is that if someone falls ill, the possible explanation is that a pixy or an ogre visits his home late at night and brings illness to him. There was a strong belief in such mysterious and strange forces. In the novel, there is deliberate marriage of history with fantasy and fiction. It is not pure history. Imagination is always there.

Thus, to make his readers know these historical elements, Ishiguro has resource to both history and his imagination. If he talks about his imagined Japan in the novels set in Japan, it is possible to speak about his imagined England. There is a blend of the real and unreal in dealing with history. It is full of fantasy. The fictional characters including the two elderly Britons, Axl and Beatrice, are immersed in their past reminiscences all throughout their journey in search of their son. Reminiscent of what happens in the Arthurian period, the two of them get encircled by some Saxon warriors bringing to the front the conflicts between the Britons and Saxons and molding everything in fiction.

\section{Conjectural History in Kazuo Ishiguro: The Rationale}

Ishiguro does not use conjectural history out of blue. There are important reasons behind that. He does not mention the Nagasaki Peace Park just to tell the story of the fall of the atomic bomb on Nagasaki and other Japanese cities and make people from all over the world remember it. His intention seems to be deeper than that. He seeks to confer on the event a divine touch. He focuses on the Statue. It is not a mere motionless and speechless Statue; it is a godly force with heavenly power to protect Japan from evil. Its greatness reflects the greatness of his imagined Japan. The Statue is described in A Pale View of Hills in such a way:

The statue resembled some muscular Greek god, seated with both arms outstretched. With his right hand, he pointed to the sky from where the bomb had fallen; with his other arm — stretched out to his left — the figure was supposedly holding back the forces of evil. His eyes were dosed in prayer. (A Pale View of Hills, 75)

What is important here is not to inform about the Statue and the atomic bomb from a purely historical point of view. These are facts which are stated and covered by historians. Ishiguro seems to feel that there are so many things untold about the Statue. There are gaps which are to be filled by fiction and through imagination and interpretation. The aforementioned description reveals the great symbolic value of the Statue in the postwar 
Japan. It has some divine power. It is architecturally orchestrated in a way to remind the world of the atrocious harm the bomb caused to Japan (the right arm) and to shield the nation from the evil forces (the left arm). The right arm pointed to the sky can be seen as a means to say that there is a heavenly power in charge of the protection of the post-war Japan. There is nothing to worry about. It is reassuring the Japanese and visitors that Japan is no longer easy to defeat since it has survived the atomic bomb. The Statue is the god who prays for the safety, wealth, peace and welfare of the Japanese nation.

Really remarkable to note is that Ishiguro seeks to fictionally show that even at that time of war and distress there are moments of joy and entertainment in the wake of the war which should not go unnoticed. Life continues regardless of how much pain and sorrow their hearts feel and carry. Wars come and leave and life goes on. No human power can put an end to it. To exemplify this, Etsuko in the company of Sachiko and her daughter Mariko go on a sort of excursion to the Hill of Inasa where there are stalls of sweets and toys, benches to sit on, picnic tables for visitors, cable-cars to get on to the top of the hill, a beautiful sea to watch, a breezy air to embrace, and people not only from post-war Japan but also from America to chat and exchange ideas with. From over the hilltop, there are breathtaking sights and splendid sceneries to discover and enjoy. Mariko plays with the binoculars Etsuko buys for her, using them to explore the area and have fun. They all walk at an easy pace, stopping from time to time to relax. The whole space confers on hearts a touch of peace, tranquility and calm. Thus, amidst the death and destruction caused by the war, there is the burning desire to survive and keep life going on, looking for moments of merriment and happiness.

Thus, there seems to be a strong reason behind the description of the beautiful sights and marvelous sceneries surrounding the hills which lead to Nagasaki in the post-war Japan. The reason is mentioned by Etsuko herself when she says from the top of the hill to Sachiko that "everything is so full of life" asking her to have a look at the area down the hill (A Pale view, 59). She gesticulates to the area which "was badly hit when the bomb fell", comparing the past with the present (ibid). The bomb brought death to the area, but now it is full of energy and life. Ishiguro seeks to demonstrate that regardless of how much damage and destruction a nation can face and experience in its history, the strong human will and determination to continue living can bring life, action, dynamism, and power to that nation. He relies on his imaginative power to deliver such a message.

By focusing on the post-war Japan especially in his early works, Ishiguro probably seeks to impart the message that the Japanese collective memory still holds in store all that happened during that period. Through fiction, he shows that the occupation of Japan and the discussion of its imminent end are among the topics preoccupying people and mass media at that specific moment of history. "The newspapers were full of talk about the occupation coming to an end and in Tokyo politicians were busy in argument with each other" (A Pale View of Hills, 53). Politics was a trending topic taking the interest of people and causing much debate among them. It was a vogue word in the Ishiguro's imagined Japanese community at that time.

Ishiguro seeks to provide a fictional account of what happens to Japan after the fall of the bomb and the US occupation. The intention is probably to argue for the view that these sad occurrences "significantly altered the Japan of Yesteryear into the present powerful nation that is known today" (Koch, Kris, 5). Japan has grown as a new superpower out of debris and ruins. It has been reconstructed into a new superpower thanks to its ability to recover and look forward and thanks to the decision and choice of the Japanese to forget the past with all its atrocities and bloodshed, to be optimistic and focus on the future. The Japanese have wisely and consciously chosen to leave the dark and tragic parts of their history just buried. The past is there to take lessons from with intent to develop and prosper. Thinking continuously about it might have deterred Japan from moving forward towards progress and affluence. It is no longer a coincidence that it is now ranked among the superpowers of the time.

The mention of Shanghai Settlement is not meant to narrate what happens exactly at that specific time and place. Ishiguro's intention as a novelist goes beyond that. He doesn't talk about it as historians do. He possibly aims at showing the suffering of many people including children from the spread of crime, corruption, kidnapping and opium trade in Shanghai at that time. Christopher Banks, the protagonist, attributes the disappearance of his parents in Shanghai to his mother's criticism of this trade. Thus, Ishiguro starts with a historical fact to make conjectures about that specific period of human history. He probably seeks to draw attention to the stories of many British children who find themselves without parents first in Shanghai and then in England upon their return to their parents' homeland. He builds on history to make conjectures about childhood and orphan-hood within the framework of tense Anglo-Chinese relationships at that time.

Christopher Banks in When We Were Orphans can be seen as a case in point. There are a lot of children who are doomed to lead a life like his with all its ups and downs. They are described in the novel as odd birds and sniveling little squirts since they are bereft of the warmth of their parents. Through the tool of fiction, Ishiguro puts fingers on the feelings of loss and estrangement these children go through in the settlement of Shanghai and how their socio-familial and psycho-economic circumstances play a determinant role in the shaping of their professional identities. Christopher Banks' aspiration is to be a detective because he wants to disentangle the intricate threads of his parents' disappearance during his childhood in Shanghai. It is so hard to 
get him go astray and change his mind towards another objective. His ambition to be a detective is embroidered with tears of sorrow he sheds as a child at the reception of the news of his parents' disappearance.

Ishiguro creates the story of Banks within a certain real historical context dating back to the end of the 19th century and the beginning of the twentieth one to describe the psychological burden so many children patiently and ambitiously carry in different stages of their lives in search for their identities. He probably feels that these are some of the things not sufficiently covered by historians at that time. Historically speaking, many British people live in the Shanghai Settlement and then return to England, but what is special about our invented story of Banks is that it casts light on a special kind of individuals whose childhood in the settlement has the upper hand in shaping who they are. Their lives are fixed with their childhood memories.

The inclusion of the International Settlement of Shanghai and the mention of the Shanghai Bund are not done for the sake of narrating history. Rather, the fictional story of Banks is meant to cast light upon the journey of many children born in the settlement in search for identity. Banks the child is split asunder between two homes: the home he knows as a child and where his parents live and exist (Shanghai); and the home he is bound for where he knows none (England). On his voyage aboard, he thinks of Shanghai as his home; whereas Colonel Chamberlain speaks of England as his home. Being before two homes puts his heart and mind in a mire of irritation and bewilderment. For Banks the orphaned child, it is a journey towards the unknown. It is a move towards the discovery of a new life and home different from the ones he is accustomed to.

By wrapping the Shanghai International Settlement with fictional stories, Ishiguro seems to draw a comparison between life in the Shanghai Settlement and other Chinese areas from the vantage point of the British settlers. Banks and his Japanese friend Akira are told by their parents that these areas are full of "ghastly diseases, filth and evil men" and that it is better for them to stay "all within the relative safety of the International Settlement" (When We Were Orphans, 33). This shows the view of the colonizer towards the colonized. It is the view of the superior self towards the inferior other. The self is associated with good, safety, cleanness and better health and the other with dirt, fear, pestilence, illnesses and wickedness. Thus, the comparison sounds to be unbalanced and unjust. It is disparagingly colonial in nature. Maybe, this is the message Ishiguro seeks to deliver through the deliberate marriage of history with fiction and imagination.

It may also sound plausible to vouch that Ishiguro's description of the Chinese districts in comparison to the Settlement is an indictment of the colonial ideology which is dehumanizing in nature. Because of colonialism, there are "no proper buildings" in these districts, "just shack upon shack built in great proximity to one another", and these buildings are "much like the marketplace in Boone Road" with "dead bodies piled up everywhere, flies buzzing all over them" (When We Were Orphans, 33). Through his protagonist, Ishiguro condemns, albeit implicitly, the colonial ideologies which make the lives of indigenous people uncomfortable and uneasy, full of death and calamities. It is an attempt on the part of him to say that history cannot forgive all the colonial powers which dye humanity now and then with blood and injustice. This is a message he imparts through his fictional description of his imagined Japan in the wake of the war.

The mention of the opium trade in When We Were Orphans is very important to consider when it comes to the conjectural use of history. Conferring a fictional touch on the history of trade opium in China is meant to show that many voices including the feminine ones stand up against it. The people in Shantung and other Chinese provinces are not the ones to be held guilty for the spread of the trade, the heavy consumption of opium, and the dissemination of corruption and all genres of crime. They are victims of certain greedy groups of politicians and merchants from China, India, England and elsewhere and thus they should not be indicted. It is the top of immorality to import opium, sell it to people and then blame them for their addiction and wrongdoings. This is the message Ishiguro seeks to impart through the eloquent and strong voice of Mrs. Banks. This lady argues that it is a real shame to fire out servants on the ground of things they are not responsible for. Ishiguro's fiction serves history in that it reveals the unwanted and unsaid parts of it.

Mrs. Banks, in "a tirade of controlled ferocity", openly criticizes the rapacious British people and companies like Morganbrook and Byatt "for importing Indian opium into China in such massive quantities," and bringing "untold misery and degradation to a whole nation" (ibid). She contends that it is a source of shame to work for such a company. By doing this, she can be considered the voice of the voiceless at that time. It is probably an attempt on the part of Ishiguro to moralize history by hinting to the point that amidst the huge heap of corruption and evil, there are always glimmering flashes of good values that readers of history should see and appreciate. But within a society overwhelmed with a colonial mode of thinking, good is mostly overshadowed with evil.

But what is special about this strong feminine voice against the opium trade is that her husband works for the company of Morganbrook and Byatt and lives in one of its houses. It is a criticism of someone who knows how the trade system works and the opium network operates. The choice of this special character to launch this criticism is so clever of Ishiguro. The choice of another character from outside the system might not yield the same effect and results. Mrs. Banks' explosion in the face of the inspector and her open condemnation of the opium trade show Ishiguro's desire to moralize history at that time. Within the overall sphere of opium, 
corruption, and injustice, there are good people who speak for virtues and good values. This history moralization is done through the inclusion of conjectures of his imaginative creation.

As for the fictionalized speech of Sir Edgar Algernon Robert Cecil in When We Were Orphans, it is meant to express animadversion against the atrocities and bloodshed caused by the War through the mouth of Sir Cecil who deprecatingly describes the War as ghastly and calamitous. Crafting this speech in this way is meant to deliver the message that the human history is full of mistakes which can result in disastrous effects on humanity, but what is important is to learn from these mistakes and optimistically look forward to a better future. The War is undoubtedly catastrophic, but it is also an "awkward window in Man's evolution". It is a gateway towards progress at the technical and organizational level. Hence, the choice of Sir Cecil as a famous figure not only in the British history but in the international one as well is no longer a coincidence. The purpose behind that is not to give a biographical account of him, but to impart the message that a better life can emanate from the ruins and debris of the War. Optimism, evolution, civilization, law, progress and organization can stem from chaos, hostility and fear.

As for the last novel, through the choice of The Buried Giant as a title, Ishiguro seeks probably to draw the historians' attention to the idea that there are so many things in the human history in general and the British one in particular which are, intentionally or unintentionally, buried and it's high time to shed some light on them. Casting some light on them is the call of morality, justice and conscience. His novel has come as an artistic attempt to put fingers on some of these buried aspects of human history. It is real history mixed with Ishiguro's conjectures or likely stories not only to fill in gaps in the works of historians but also to give free rein to readers and critics to come up with their personal interpretations and readings of the historical period in focus.

Another important point to add concerning the setting of The Buried Giant is that its events date back to the historical period related to King Arthur who is regarded by medieval histories and romances as a legendary British leader who led the defense of Britain against the Anglo-Saxon invaders coming from the Germanic tribes of Angles and Saxons in the fifth century (David MacDowall, 1989, 16). Kazuo Ishiguro is very much concerned with how everything suddenly turned out to be Anglo-Saxon. He is trying to question the feasibility and credibility of the historical data provided by history books about what happened exactly to the indigenous people of Britain as a result of the Anglo-Saxon invasion. He assumes that there are a lot of missing points and historical gaps that need to be filled in as far as the British history is concerned.

Ishiguro finds it very interesting and pertinent to tackle the issues of superstition and myths in his fictional works. For him, ogres and pixies are like extras or background actors in a movie in the sense that the events of the novel are rolling whereas the pixies and ogres are in the back without moving or uttering a word. They are there in the background. He justifies their presence in the novel by saying that "they stand for quite powerful and scary things" because "they are very much associated with illness and death". Incorporating such supernatural creatures in the fabrics of the story of the novel is meant to show the spread of superstition in Britain in the period just around the fifth and sixth centuries.

It can be also seen as a tactic possibly used to show that the current England is totally different from the past one. Science and knowledge have made of it a developed country which resorts to reason and logic to explain the existing phenomena. He probably seeks to debunk the spread of mythological thoughts and superstitious beliefs at that time in the Anglo-Saxon Britain. Maybe, his intention is to show that being superstitious is something deeply rooted in the British history and, thus, it is an exercise in futility to limit the existence of superstition to some specific societies which are now categorized as developing or under-developed, forgetting that even the developed ones can remarkably witness the presence of such phenomena.

\section{Conjectural History in Kazuo Ishiguro: Implications}

There are some important implications to draw from Kazuo Ishiguro's marriage of historical facts with imagination, fiction and conjectures. The example aforementioned concerning the fictionally crafted speech of Sir Cecil can be understood as a way on the part of Ishiguro imply that humanity did not learn from its mistakes since another tragic war broke out. Lessons were not intelligently drawn from the First World War in the interwar period of human history and consequently a second one took place causing more casualties and destruction. Voices of wisdom and peace were not heard and privileged. Militarism continued to hold sway in the international scene, reaping more human lives. There is a far cry between Sir Cecil's optimistic discourse and the reality. The failure of this discourse at that time signals the failure of the League of Nations. One more thing, the speech and the chat Sir Cecil has with Banks hold the heads of States at that time responsible for the outbreak of the Second World War. It is a sort of indictment of the political decision makers not only at that time but also now for not being able to eschew bloodshed and death.

Very important to note is that though the stories of the three novels are set in the past, they have a lot to say about modern societies. There are always some recurring patterns that are repeated again and again just because they are part of the human life. The Buried Giant, for instance, refers actually to the dark past memories, bloody atrocities and brutal genocides and wars that human history has incessantly known and that are buried 
somewhere in the memory and are to be resurrected at any time. In this novel, in what Ishiguro sees as a blank historical canvass, the question of whether the indigenous Britons were subject to some sort of ethnic genocide in post-Roman Britain is raised. Recent history is unfortunately crammed full with genocides, racial segregation, wars, armed conflicts, terrorist attacks, and apartheid and suchlike. Bloodshed is a common mode of discourse and communication that many nations may use and adopt to preserve their interests and keep their power. It is not something which belongs to bygones, but it happens over and over all throughout the human history.

In the same vein, dealing with this specific period in The Buried Giant, around the fifth and sixth centuries, can be considered an adventure on the part of Kazuo Ishiguro taking into account the fact that historians themselves do not agree about it. This means by implication that Kazuo makes very significant hints at the history of Britain not just to dust it and shed light on the buried part of it. Rather, he seeks to show that history in many cases and contexts repeats itself. Maybe, the intention is to draw attention to the idea that in the history of each individual and nation, there is something hidden and buried. As individuals, communities and nations, humans find themselves facing important questions: how should they deal with their history? What should they remember and what should they forget? And when should they remember or forget history? What happens if they forget? And what happens if they remember? These are some of the perplexing questions which continuously float into the minds of people as individuals and communities while dealing with history.

The journey portrayed in The Buried Giant is of focal importance in the textile of the story. It is a journey in time to re-new contact with the past and to remove the dominant mist. It is a journey to re-discover the dark episodes of this past. In clear terms, it is a movement towards a graveyard where all gigantic past sufferings and atrocities are buried and hidden in the mud of forgetfulness. It is the mist graveyard of the dead and forgotten memories. It is a trip to unearth the giants buried in this graveyard of forgetfulness. This means, once again, by implication that the world humans live in is surrounded with graveyards of buried memories, both good and bad. It's up to individuals and nations to decide to either forget them or rake them up. It's up to them to either keep them buried or bring them to the spotlight.

It is a voyage towards untangling some of the threads of a long-standing conflict between two powers: the power of memory and that of forgetfulness. With the mist everywhere, our protagonists, Axl and Beatrice, seem to lose their power of memory. Even those very important events related to their very intimate love relationship evaporate in the mist and forgetfulness. Viewed from this perspective, the journey is an important channel through which Axl and Beatrice can move from the world of forgetfulness and mist to that of remembrance and clarity. This means by implication that in so many occasions human beings get trapped in the mire of forgetfulness and remembrance now and then, confronted with the dilemma of what to forget and what to remember.

The example that Kazuo loves to give when highlighting the importance of forgetting the dark history of humans is that of South Africa which suffered for years from the racial apartheid. Many inhuman and tragic incidents occurred in this country until 1996 when this apartheid ended. The fact that the people in this country decided to forget everything and focus on building their peaceful, harmonious and unified nation has made of them one of the greatest democracies in the world in twenty years' time. The resurrection and remembrance of this dark history may develop into a civil war. It may end up in disintegrating the whole nation and spreading hatred and conflicts in the society. Giving this example, among many others, in relation to the novel is of paramount importance as it reveals the universal dimension of the novel.

\section{Conclusion}

Kazuo Ishiguro, in fact, seems to show an interest in history and past memories not for their own sake. He himself says that he is not being historical. He makes use of historical facts and wraps them with fiction to impart certain messages, fill in some gaps in history, and give free rein to readers to come up with their interpretations and conclusions. He is actually concerned with the ability of people to remember or forget the bad and tragic historical events that are usually buried and hidden for one reason or another. He uses the word giant in his last novel to refer to them to show their gigantic and detrimental impact when they are resurrected.

Remembering them may cause harm to people as individuals, communities and nations and may disseminate hatred among them. For this reason, he raises the question of what humans should remember and what they should forget. Malicious people, institutions, and organizations may rake up these events to create hatred and conflicts among individuals, nations and societies. That's why it's better to forget these atrocities and genocides, to focus on the present and think about the future. It is good to resort to the past from time to time but just to learn from it.

\section{References}

Anastas, Benjamin. Keeping it Real. 3 Oct. 2000, A Book Review www.villagevoice.com/2000/10/03/keeping-itreal/. Print.

An interview with Kazuo Ishiguro on TVO, conducted by Piya Chattopadhyay on July 222015 
https://www.youtube.com/watch?v=QizILvkdgnk

Brewer, Anthony. Adam Smith's stages of history. Mar. 2008. Discussion Paper No. 08/60, Department of Economics,University of Bristol 8 Woodland Road Bristol BS8 1TN. Print.

David MacDowall. An Illustrated History of Britain. Longm an Group UK Limited 1989, p 16. Print.

Ishiguro, Kazuo . A Pale View of Hills. Knopf Doubleday Publishing Group (1990). An Electronic PDF Version. 1982. Print.

Ishiguro, Kazuo. The Buried Giant (e-book ed.). London: Faber and Faber. ISBN 978-0-571-31505-5. 2015. Print.

Ishiguro, Kazuo. When We Were Orphans. An Electronic PDF Version. 2000. Print.

JOHNSON, GAYNOR. Lord Robert Cecil as an internationalist: A mental map. 2010, http://usir.salford.ac.uk/19251/. Print.

Keller, Wolfgang, et al. Shanghai's Trade, China's Growth: Continuity, Recovery, and Change since the Opium War. 2012, spot.colorado.edu/ kellerw/sh.pdf. Print.

Koch, Kris . The US Occupation of Japan (In what way did it influence Japan?). 24 Mar. 1999.

Perdue, Peter C. The First Opium War The Anglo-Chinese War of 1839-1842. ocw.mit.edu/ans7870/21f/21f.027/opium wars 01/ow1 essay.pdf. Print.

Teo, Yugin. Kazuo Ishiguro and Memory. PALGRAV̄E MAC̄MILLAN (2014), P 1. Print.

Tina Srebotnjak's Interview with Kazuo Ishiguro, March 17, 2015. The Bram and Bruma Appel Salon at the Toronto Public Reference Library, https://www.youtube.com/watch?v=Wg88dMl2d6s. Print.

Webley, Alyn. Making and Braking Hegemonies : Kazuo Ishiguro and History. Postgraduate English ISSN 17569761. March 2006, Issue 13. Print.

Wyer, Robert S., and Thomas K. Srull. Memory and Cognition in its Social Context. Psychology Press. Waterstones, Taylor \& Francis Inc, 12 Nov. 1989, www.waterstones.com/book/memory-and-cognition-inits-social-context/robert-s-wyer-jr/robert-s-wyer/9780805805994. Print. 